\title{
The effects of weather on milk production in dairy sheep vary by month of lambing and lactation phase
}

\author{
Jose Alfonso Abecia • Angel Garcia • Laura Castillo - Carlos Palacios
}

JA Abecia (Corresponding author)

Instituto Universitario de Investigación en Ciencias Ambientales (IUCA). Facultad de Veterinaria. Miguel Servet 177, 50013, Zaragoza, Spain.

e-mail: alf@unizar.es

\section{A Garcia - C Palacios}

Departamento de Construcción y Agronomía. Facultad de
Ciencias Agrarias y Ambientales. Universidad de Salamanca, Spain.

\section{Castillo}

Departamento de Ciencias Pecuarias. Facultad de Estudios Superiores Cuautitlán, Universidad Nacional Autónoma de México, México.

Received: February 01, 2017 • Revised: February 21, 2017 • Accepted: March 02, 2017

\begin{abstract}
A total number of 609 bulk-tank milk controls on a dairy sheep farm in Spain were used to determine how weather affects milk production in sheep, related to lambing period and lactation phase. Data from individuals were assigned to one of five lactation periods based on the timing of lambing: FEB ( $n=124)$; APR $(n=141)$; JUL $(n=114)$; SEP $(n=102)$, and NOV $(n=128)$. Milk yield per ewe per day was calculated as total milk volume/number of ewes milked. Lactation was divided into three phases: Early-lactation (from lambing to month 2), Mid-lactation (from month 3 to 7 ), and Late-lactation (month 8). Milk yield per ewe was higher $(\mathrm{P}<0.01)$ in SEP than in FEB, APR, or NOV; production peaked in JUL and was lowest in FEB. In lactations initiated in JUL and SEP, milk yield per ewe per day was higher $(\mathrm{P}<0.05)$ in early lactation than it was in the other lambing periods; however, in APR and SEP, per ewe production was highest $(\mathrm{P}<0.01)$ in mid-lactation. Milk yield in each of the five lambing periods was significantly $(\mathrm{P}=0.001)$ associated with several meteorological variables, and the strongest $\left(\mathrm{R}^{2}=0.732\right)$ was with solar radiation and minimum temperature in the APR lactation period. In all lactation periods, the relationship between milk yield and weather differed among the three phases of lactation. In conclusion, the effects of meteorological conditions on milk yield in sheep cannot be understood without assessing production among milking periods in the same year and the phases of lactation, especially if milking periods are long.
\end{abstract}

Keywords: meteorology, month, ovine

\section{Introduction}

Climate and weather can have strong influences on farm animal production systems because they can be environmental stressors that, if they affect physiological processes, have a negative effect on animal welfare and productivity (Gomes Da Silva 2006). Meteorological conditions can impair growth, reproduction efficiency, and milk production because temperature has significant direct effects on biological functions (Silanikove 2000). Meteorological factors such as temperature, humidity, wind velocity, and radiation are environmental factors that can influence the comfort and stress levels of animals (Naskar et al 2012).

The effects of weather on milk yield have been well studied in dairy cattle, sheep, and goats, although most studies have focused on the effects of heat stress on milk yield (reviews: cattle, Blackshaw and Blackshaw, 1994; sheep, Marai et al 2007; goats, Lu 1989). However, in Manchega sheep, for example, cold stress had a greater negative effect on milk yield than did heat stress (Ramon et al 2016). In addition to weather, artificial selection to increase milk production has reduced heat tolerance in dairy cattle (Bohmanova et al 2007) and dairy sheep (Finocchiaro et al 2005). Therefore, milk yield is antagonistic to heat tolerance, and selection for increased milk production, only, will reduce heat tolerance.

Temperature and relative humidity can affect milk yield; for example, air temperature and milk production in cows are negatively linearly correlated (West et al 2003). Caroprese et al (2011) reported some variation in milk composition in ewes that had been exposed to solar radiation in the summer, although another study showed that exposure to solar radiation did not have significant effects on milk yield and composition in dairy ewes that had been provided with shaded areas (Sevi et al 2001), which suggests that providing shaded areas can be important in minimizing the adverse effects of high ambient temperatures on thermal balance in lactating ewes. The potential for rainfall to affect productivity in small ruminants is more strongly associated with an effect the availability of grass than with a direct effect on the physiological processes that influence 
reproductive success (Arrébola et al 2009). In one semiextensive sheep system in the Mediterranean region, variation in annual rainfall produced inter-annual variation in forage availability, which influenced animal performance (Scocco et al 2016). Some bioclimatic factors are biologically significant climate variables that can be used to predict the impact of climate change on grazing season length on European farms (Phelan et al 2016).

The objective of this study was to quantify the effects of weather on milk yield in a dairy sheep farm. The farm used a five-lambing period system, and the average lactation period was long (nine months); therefore, the study focused on the effects of weather on milk yield among lambing periods and phases of lactation.

\section{Materials and Methods}

The study was carried out on an Assaf dairy sheep farm in Olmedo, Spain $\left(41^{\circ} 30^{\prime} \mathrm{N}\right)$. In the area, the climate is "dry-summer temperate" (Csb by Köppen and Geiger); i.e. warm and temperate Mediterranean. Annual precipitation is about $395 \mathrm{~mm}$, and monthly precipitation is lowest in August $(12 \mathrm{~mm})$ and highest in May $(47 \mathrm{~mm})$. Average annual temperature is $12.2^{\circ} \mathrm{C}$, and monthly average temperature is highest in July $\left(21.7^{\circ} \mathrm{C}\right)$ and lowest in January $\left(3.8^{\circ} \mathrm{C}\right)$.

The farm had 950 ewes and 45 rams and followed a reproductive calendar that was adapted from the STAR system (Lewis et al 1996), which is based on five mating periods per year (ram introduction for $30 \mathrm{~d}$ in February, April, June, September, and November) and five lambing periods (July, September, November, February, and April, respectively). The flock had access to open parks, and ewes were fed to meet their nutritional requirements based on their level of production. Ewes were weaned from their lambs immediately after parturition, machine milked twice daily, and had their lambs reared artificially, which were offered colostrum and milk substitutes.

From January 2014 to March 2015, 609 bulk-tank milk controls were performed. Individuals in the flock were assigned to one of five groups based on its lambing period: FEB ( $n=124$ controls), APR ( $n=141$ controls), JUL ( $n=114$ controls), SEP ( $n=102$ controls), and NOV ( $n=128$ controls). Milk yield per ewe per day was calculated as total milk volume/number of ewes milked. Milk yield in the tank of each group was measured separately. Lactation period was up to $240 \mathrm{~d}$, and was assessed in three phases: Early-lactation (from lambing (month 0) to the peak in month 2), Midlactation (months 3 to 7), and Late-lactation (month 8).

The Assaf dairy breed was developed in Israel by crossbreeding East Friesian (5/8) and Awassi (3/8) breeds and has been exported to other countries in the Mediterranean region. In 2016, more than 1.5 million Assaf ewes were used in milk production in Spain.
Meteorological variables

Mean, maximum, and minimum ambient temperatures $\left(\mathrm{T},{ }^{\circ} \mathrm{C}\right)$, mean relative humidity $(\mathrm{RH}, \%)$, wind speed $(\mathrm{m} / \mathrm{s})$, mean solar radiation $\left(\mathrm{SR}, \mathrm{MJ} / \mathrm{m}^{2}\right)$, and total rainfall $(\mathrm{mm})$ on each control day were obtained from the meteorological station in Olmedo (Valladolid) (1.5 km from the farm). The temperature-humidity index (THI), which was based on the formula of Marai et al (2007), was as follows:

$$
\mathrm{THI}=\mathrm{T}-(0.31-0.0031 \times \mathrm{RH}) \times(\mathrm{T}-14.4)
$$

where $\mathrm{T}=$ air temperature $\left({ }^{\circ} \mathrm{C}\right)$ and $\mathrm{RH}=$ relative humidity .

Marai et al (2007) defined four heat-stress categories: THI $<22.2=$ absence of heat stress, $22.2 \leq$ THI $<23.3=$ moderate heat stress, $23.3 \leq \mathrm{THI}<25.6=$ severe heat stress and $\mathrm{THI} \geq 25.6=$ extreme severe heat stress. A preliminary analysis indicated that mean $\mathrm{THI}=11.94$, the standard deviation was low $( \pm 6.33)$, THI did not differ significantly among lambing periods (FEB: 14.6; APR: 12.9; JUL: 11.2; SEP: 10.3 ; NOV: 10.3), and $95 \%$ of the THI indicated "absence of heat stress"; therefore, THI was not included in the analysis.

Statistical analysis

Milk yield was analyzed using the least squares method of the GLM procedure in SPSS (IBM SPSS 2013) and fitting a one-way model with a fixed effect of month of lambing or lactation period. The general representation of the model is as follows: $\mathrm{y}=\mathrm{xb}+\mathrm{e}$, where $\mathrm{y}$ is $\mathrm{N} \times 1$ vector of records, $b$ denotes the fixed effect in the model with the association matrix $x$, and $\mathrm{e}$ is the vector of residual effects. Pearson coefficients of correlation were used to quantify the relationships between milk yield and meteorological factors. The multiple regression equations between daily milk yield per ewe and the meteorological variables were tested using a stepwise regression procedure (forward selection). $\mathrm{P} \leq 0.05$ was considered statistically significant.

\section{Results}

Monthly number of milking ewes, total amount of milk produced per day, and milk produced per ewe per day in the five lambing periods is shown in Figure 1. Mean ( \pm S.E.M.) number of milking ewes was $372 \pm 7$ and differed significantly among lambing periods (Table 1). Mean milk yield per ewe per day was $1.21 \pm 0.021$, and mean total milk yield per day was $463 \pm 12$ l. The five lambing periods differed significantly (Table 1); specifically, SEP had the fewest number of milking ewes $(\mathrm{P}<0.01)$ and, consequently, 
total milk yield per day was lowest among the five lambing periods $(\mathrm{P}<0.001)$; however, milk yield per ewe per day was significantly $(\mathrm{P}<0.01)$ higher in that period than it was in the
FEB, APR, or NOV. Yield was highest in JUL and lowest in FEB lactations (Table 1).

Table 1 Mean $( \pm$ SEM) number of milking ewes, mean milk production (1/ewe/day), total milk production (1/day), and peak of production (1/ewe/day) of Assaf ewes on a farm in Spain, that had five lambing periods per year (Feb, Apr, Jul, Sep, Nov).

\begin{tabular}{lcccc}
\hline & Milking ewes & Milk/ewe/day & Milk/day & Peak \\
\hline February & $408 \pm 15^{\mathrm{a}}$ & $1.13 \pm 0.03^{\mathrm{a}}$ & $461 \pm 24^{\text {ace }}$ & $1.60 \pm 0.04^{\mathrm{bc}}$ \\
April & $533 \pm 13^{\mathrm{b}}$ & $1.20 \pm 0.04^{\mathrm{c}}$ & $636 \pm 34^{\text {bde }}$ & $2.02 \pm 0.05^{\mathrm{b}}$ \\
July & $379 \pm 10^{\mathrm{c}}$ & $1.26 \pm 0.05$ & $473 \pm 23^{\mathrm{ce}}$ & $2.08 \pm 0.03^{\mathrm{a}}$ \\
September & $145 \pm 6^{\mathrm{d}}$ & $1.32 \pm 0.04^{\mathrm{bde}}$ & $193 \pm 10^{\text {bcf }}$ & $1.92 \pm 0.05^{\mathrm{b}}$ \\
November & $336 \pm 9^{\mathrm{e}}$ & $1.16 \pm 0.03^{\mathrm{f}}$ & $389 \pm 19^{\mathrm{bce}}$ & $1.70 \pm 0.04^{\text {bd }}$ \\
\hline
\end{tabular}

Different superscripts in the same column indicate $\mathrm{P}<0.05$

In lactations initiated in JUL and SEP, milk yield per ewe per day was significantly $(\mathrm{P}<0.05)$ higher in early lactation than it was in the others; however, in APR and SEP, per ewe production was highest $(<0.01)$ in mid-lactation (Figure 2).

Milk yield was significantly $(\mathrm{P}<0.01)$ correlated with mean $\mathrm{T}(0.153)$, maximum $\mathrm{T}(0.149)$, minimum $\mathrm{T}$ (0.137), RH (-0.129), and SR (0.119), but not with wind speed ($0.026)$ or rainfall $(-0.008)$. In each of the three lactation phases, milk yield was highly significantly correlated with the three $\mathrm{T}$ measurements, except in FEB, when milk yield and $\mathrm{T}$ were not correlated (Table 2).

In SEP and NOV, milk production was negatively correlated with SR. RH and milk production were significantly positively correlated in SEP and NOV, and negatively correlated in FEB, APR, and JUL lactation periods. In all five periods, milk yield and rainfall were not significantly correlated.

Table 2 Correlation matrix between milk production per ewe per day and meteorological factors on the day of milk control for Assaf ewes on a farm in Spain, that had five lambing periods per year (Feb, Apr, Jul, Sep, Nov). (T: temperature, ${ }^{\circ} \mathrm{C}$; RH: Relative humidity, \%; SR: Solar Radiation, $\mathrm{MJ} / \mathrm{m}^{2}$ ).

\begin{tabular}{lccccc}
\hline & FEB & APR & JUL & SEP & NOV \\
\hline Mean T & 0.067 & $0.795^{* * *}$ & $0.521^{* * *}$ & $-0.361^{* * *}$ & $-0.595 * * *$ \\
Maximum T & 0.086 & $0.770^{* * *}$ & $0.557 * * *$ & $-0.383^{* * *}$ & $-0.595 * * *$ \\
Minmum T & -0.079 & $0.700^{* * *}$ & $0.463 * * *$ & $-0.207 *$ & $0.528 * * *$ \\
RH & $-0.372 * * *$ & $-0.761 * * *$ & $-0.386^{* *}$ & $0.610^{* * *}$ & $0.571^{* * *}$ \\
Wind speed & $0.198^{*}$ & 0.060 & $-0.246 * *$ & -0.118 & 0.075 \\
SR & $0.412^{* * *}$ & $0.797 * * *$ & $0.472^{* * *}$ & $-0.687 * *$ & $-0.631^{* * *}$ \\
Rainfall & 0.119 & -0.020 & -0.005 & -0.133 & -0.025 \\
\hline$*$ P<0.05; *** P<0.001 & & & & &
\end{tabular}

In the overall step-wise multiple regression analysis of the correlation between milk yield per ewe per day and meteorological variables, mean $\mathrm{T}$ was the only variable introduced into the regression equation $\left(\mathrm{R}^{2}=0.023, \mathrm{P}=0.001\right)$; however, regression analyses for each lambing period, individually, indicated that milk yield in the five lambing periods was significantly $(\mathrm{P}=0.001)$ correlated with several meteorological variables, and the strongest $\left(\mathrm{R}^{2}=0.732\right)$ correlations were with $\mathrm{SR}$ and minimum $\mathrm{T}$ in the APR lactation period (Table 3). The correlations with the meteorological variables were positive or negative within lambing periods. In all lactation periods, the relationships between weather variables and milk yield differed significantly among the three lactation phases (Table 3 ). In some phases in some lactation periods, none of the correlations was significant, particularly, in the two lambing periods in which milk yield was the highest; specifically, in the early lactation phase of JUL, and in the mid and late phases of SEP, milk yield was not significantly correlated with any of the weather variables.

\section{Discussion}

The high number of lactating periods on the farm provided an opportunity to study the effect of weather on Assaf sheep milk production throughout the year, and the 
long (9 mo) milking period provided an opportunity to quantify the effects of weather in the three phases of the lactating period. In the FEB lambing period, for example, ewes began the milking period in winter, reached peak production in spring, had mid-lactation in spring and summer, and finished in autumn. The feed system on the farm offered food to ewes indoors and the same diet yearround, which eliminated any potential for changes in food quality to have an effect on milk yield, which is a main source of variation in milk secretion.

Table 3 Step-wise multiple regression analysis of the relationship between milk production per ewe per day and meteorological factors throughout lactation, in early lactation (lambing-month 0- to the peak, in month 2), in mid-lactation (month 3 to 7), and in late-lactation (month 8) in Assaf ewes on a farm in Spain, that had five lambing periods per year (Feb, Apr, Jul, Sep, Nov). (T: temperature, ${ }^{\circ} \mathrm{C}$; RH: Relative humidity, \%; SR: Solar Radiation, $\mathrm{MJ} / \mathrm{m}^{2}$ ). (-) means negative effect.

\begin{tabular}{|c|c|c|c|c|c|}
\hline \multicolumn{6}{|c|}{ Entire Lactation } \\
\hline Group & FEB & $\overline{\mathrm{APR}}$ & JUL & SEP & NOV \\
\hline Months & Feb-Oct & Apr-Dec & Jul-Mar & Sep-May & Nov-Jul \\
\hline Variables in & SRMax & SR & $\operatorname{Max} T$ & SR (-) & SR (-) \\
\hline \multirow[t]{2}{*}{ the equation } & $\mathrm{T}(-)$ & $\operatorname{Min} \mathrm{T}$ & Wind (-) & $\operatorname{Max} T$ & Min T(-) \\
\hline & RH (-) & & & Wind (-) & \\
\hline $\mathrm{R}^{2}$ & 0.262 & 0.732 & 0.368 & 0.537 & 0.436 \\
\hline $\mathrm{P}$ & 0.001 & 0.001 & 0.001 & 0.001 & 0.001 \\
\hline \multicolumn{6}{|c|}{ Early lactation } \\
\hline Group & FEB & APR & JUL & SEP & NOV \\
\hline Month & Feb-Apr & Apr-Jun & Jul-Sep & Sep-Nov & Nov-Jan \\
\hline Variables in & Mean T Wind (- & $\operatorname{Max} T(-)$ & --- & $\mathrm{RH}$ & Wind \\
\hline the equation & ) Rainfall & RH (-) & & $\operatorname{Max} \mathrm{T}$ & \\
\hline $\mathrm{R}^{2}$ & 0.387 & 0.763 & --- & 0.851 & 0.249 \\
\hline $\mathrm{P}$ & 0.004 & 0.001 & --- & 0.001 & 0.035 \\
\hline \multicolumn{6}{|c|}{ Mid Lactation } \\
\hline Group & FEB & APR & JUL & SEP & $\mathrm{NOV}$ \\
\hline Month & May-Sep & Jul-Nov & $O c t-F e b$ & $D e c-A p r$ & Feb-Jun \\
\hline Variables in & $\operatorname{Min} \mathrm{T}(-)$ & RH & RH (-) & --- & --- \\
\hline the equation & Mean $\mathrm{T}$ & $\operatorname{Max} T(-)$ & & & \\
\hline $\mathrm{R}^{2}$ & 0.238 & 0.478 & 0.822 & --- & --- \\
\hline $\mathrm{P}$ & 0.001 & 0.009 & 0.001 & --- & --- \\
\hline \multicolumn{6}{|c|}{ Late lactation } \\
\hline Group & FEB & APR & JUL & SEP & $\mathrm{NOV}$ \\
\hline Month & Oct & Dec & Mar & May & Jul \\
\hline Variables in & RH (-) & Wind & RH (-) & --- & --- \\
\hline the equation & & SR (-) & $\operatorname{Max} T(-)$ & & \\
\hline \multicolumn{6}{|c|}{ Mean T } \\
\hline $\mathrm{R}^{2}$ & 0.634 & 0.684 & 0.747 & --- & --- \\
\hline $\mathrm{P}$ & 0.001 & 0.002 & 0.001 & --- & --- \\
\hline
\end{tabular}

SEP lactations produced the highest milk yield per ewe per day, even though the number of milking ewes was lowest in that period. Although the farm followed an intensive reproductive system -five mating periods per year-, the inherent seasonality of reproduction in sheep was responsible for the low number of pregnant ewes in spring and, consequently, the fewest milking ewes in autumn. Such seasonality in the proportion of ewes being milked has been observed in other dairy sheep flocks in accelerated lambing systems (four lambings in three years); e.g., Awassi and Assaf breeds (Eyal et al 1978) and Karagouniko $\times$ Mytilene crosses (Menegatos et al 2005), and are explained by the 
lowest fertility rate of the spring mating period. In our study, milk yield was lowest in the FEB and NOV groups, and highest in the SEP group, which differed from other studies in dairy sheep. In Italy, Carta et al (1995) observed that production was lowest in August and highest in spring, especially April. Similarly, in Greece, summer lambing produced the highest milk yield (Menegatos et al 2006); however, in Israel, milk yields in Assaf ewes were relatively high in lactations that began in between January and March (Gootwine and Pollott 2000). Both of those studies involved semi-extensive dairy sheep flocks, and were explained by pasture availability and quality, and the flock in Israel was kept indoors, and a significant heat load and photoperiod effects were responsible for the results.

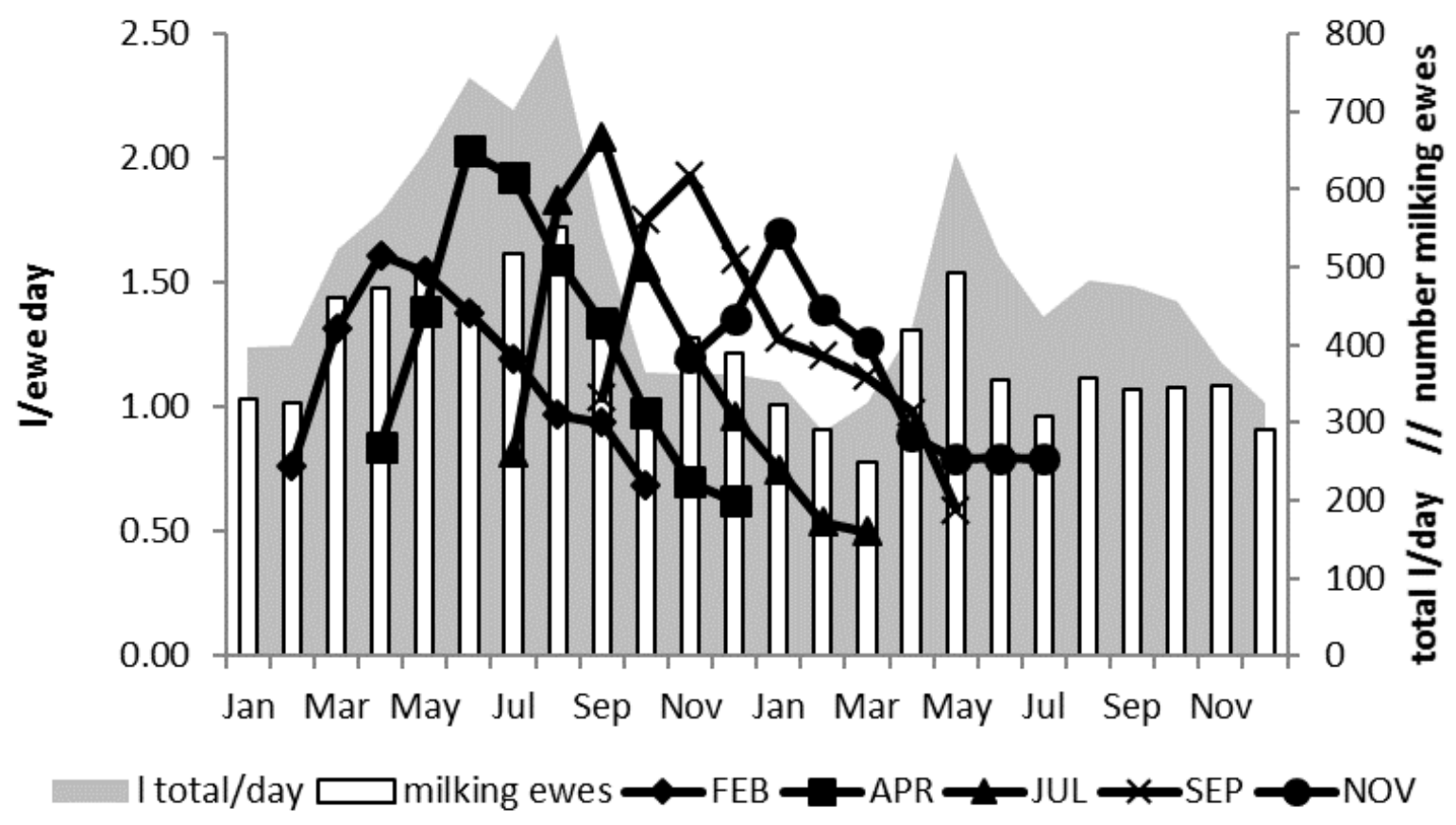

Figure 1 Monthly number of milking ewes (white bars), and total amount of milk produced per day (1/day) (shadow area) and per day per ewe (1/ewe/day) (black lines) of Assaf ewes on a farm in Spain, that had five lambing periods per year (Feb, Apr, Jul, Sep, Nov).

Few studies have investigated the effects of a group of weather variables on milk yield in small ruminants or dairy cattle. In Colombia, Echeverri and Restrepo (2009) reported that T, SR, and cloudiness had significant effects on milk yield through their effects on pasture availability. In that study, the focus was on heat stress, as measured by THI index. In a study by Barash et al. (2001), cows in the second month (peak milk yield) were more vulnerable to the negative effects of temperature than were cows in the ninth month of lactation, and a high THI did not have a significant effect on milk yield and quality in the first third of lactation, but was significantly negatively correlated with milk yield and quality in the middle and at the end of lactation (Cincović et al 2010). Apparently, in early lactation, milk secretion is influenced by the animal's sources of energy but, in the mid and the late phases, it is influenced by the energy obtained from food (Bernabucci et al 2010). The mechanisms underlying the effects that meteorological factors had on milk yield in our study remain to be elucidated. Although the overall regression analysis indicated that only mean $\mathrm{T}$ explained a significant amount of the variance in milk yield, analyses among milking periods and phases indicated that the relationship between weather and milk yield is complex. In our study, in general, temperature affected milk yield in all milking periods except NOV. Similarly, the other meteorological variables were significantly correlated with milk yield in some of the lambing periods and phases of lactation. Peana et al (2007) reported that milk yield in Sarda ewes decreased $20 \%$ when minimum $\mathrm{T}$ changed from 9-12 ${ }^{\circ} \mathrm{C}$ to $18-21{ }^{\circ} \mathrm{C}$. In addition, milk yield was reduced when the mean THI increased from $60-65$ to $72-75$, and milk yield increased by $10 \%$ when wind speed increased from 1.5-2.5 $\mathrm{m} / \mathrm{s}$ to $2.5-4 \mathrm{~m} / \mathrm{s}$. In Sicilian ewes, high $\mathrm{SR}$ and rainfall increased somatic cell count, which suggested that it is important to include weather information in genetic evaluation models for mastitis resistance (Finocchiaro et al 2007). In Italy (Caroprese et al 2011), protection from SR in summer did not improve milk yield, but milk from ewes that had been exposed to SR had reduced long-chain fatty acids and polyunsaturated fatty acids; specifically, reduced vaccenic acid, rumenic acid, and total conjugated linoleic acid contents. Clearly, weather can affect milk quality and quantity. 


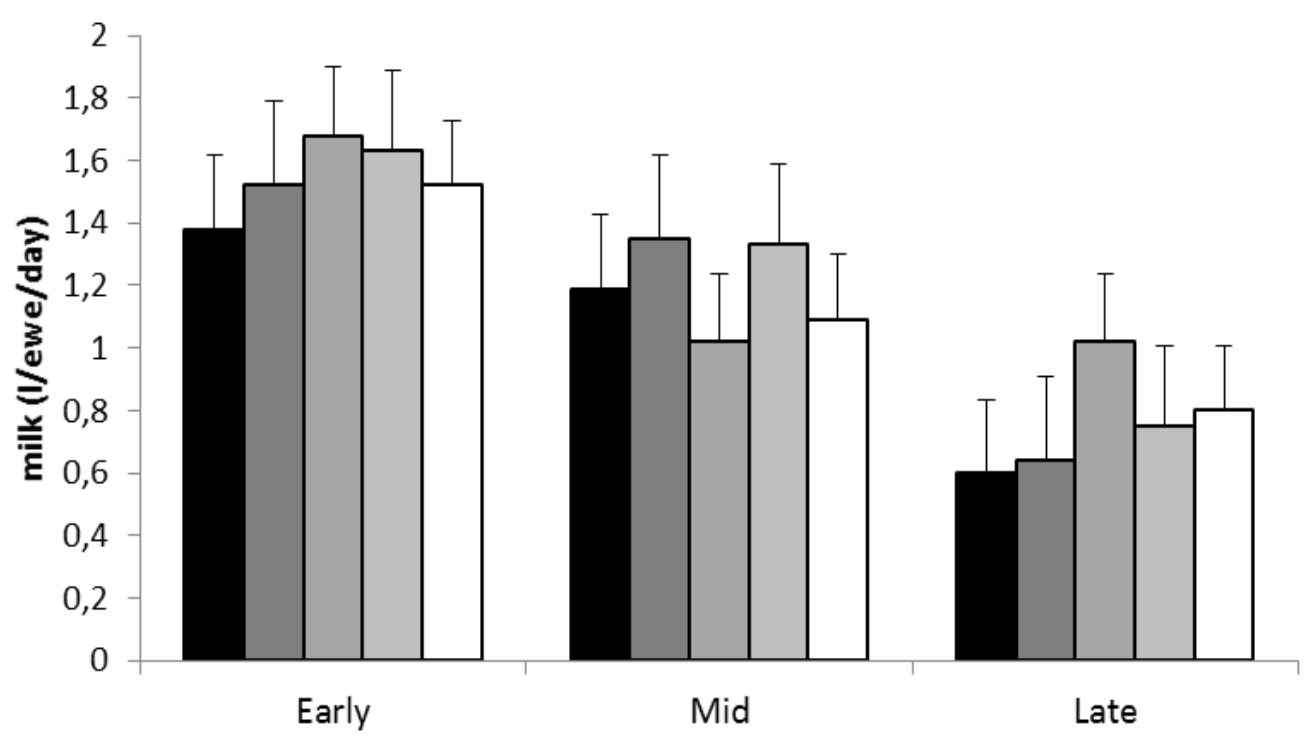

-FEB $\square$ APR $\square J U L$ LSEP $\square$ NOV

\begin{tabular}{|c|c|c|c|c|c|}
\hline \multicolumn{6}{|c|}{$\mathrm{P}$ values between groups } \\
\hline \multicolumn{6}{|c|}{ Early lactation } \\
\hline & FEB & APR & JUL & SEP & NOV \\
\hline FEB & & $>0.05$ & 0.014 & 0.047 & $>0.05$ \\
\hline APR & & & $>0.05$ & $>0.05$ & $>0.05$ \\
\hline JUL & & & & $>0.05$ & $>0.05$ \\
\hline SEP & & & & & $>0.05$ \\
\hline \multicolumn{6}{|l|}{ NOV } \\
\hline \multicolumn{6}{|c|}{ Mid lactation } \\
\hline & FEB & APR & JUL & SEP & NOV \\
\hline FEB & & 0.014 & 0.009 & 0.032 & $>0.05$ \\
\hline APR & & & 0.0001 & $>0.05$ & 0.0001 \\
\hline JUL & & & & 0.0001 & $>0.05$ \\
\hline SEP & & & & & 0.0001 \\
\hline NOV & & & & & \\
\hline
\end{tabular}

\begin{tabular}{ccccc}
\hline \multicolumn{5}{c}{ Late lactation } \\
\hline FEB & APR & JUL & SEP & NOV \\
\hline FEB & 0.285 & 0.0001 & 0.009 & 0.0001 \\
APR & & 0.0001 & 0.05 & 0.0001 \\
JUL & & & 0.0001 & 0.002 \\
SEP & & & & $>0.05$ \\
NOV & & & & \\
\hline
\end{tabular}

Figure 2 Mean $( \pm \mathrm{SEM})$ milk production per ewe per day throughout lactation, in early lactation (lambing-month 0- to the peak, in month 2), in mid-lactation (month 3 to 7), and in late-lactation (month 8), and mean and peak production by Assaf ewes on a farm in Spain, that had five lambing periods per year (Feb, Apr, Jul, Sep, Nov). P-values for the differences between groups are indicated, below.

In our study, the climate of the region did not produce a THI index that was high enough (mean $\mathrm{T}$ in July: $21.7^{\circ} \mathrm{C}$ ) to assess the effects of heat stress on milk yield in Assaf ewes in this part of Spain. Although the effects of heat stress on animal physiology have been well studied, the effects of other factors such as SR, wind speed, and rain on sheep physiology have not. In dairy goats, heat stress causes significant changes in metabolic functions, gene expression, 
inflammatory status, and productivity (Salama et al 2014). In sheep, exposure to high ambient temperatures increases efforts to dissipate body heat, which involves increases in respiration rate, body temperature, and water consumption, and a reduction in feed intake (Marai et al 2007), which can reduce milk secretion. As $\mathrm{RH}$ increases, the effectiveness of evaporative heat loss is reduced and the maintenance costs of heat loss are subsequently increased (Finch 1985). Wind speed, thermal insulation of the fleece, fleece length, and the radius of the animal influence external insulation, and surface temperature, body temperature, surface area, and body insulation of the animal affect heat loss (Pluske et al 2010).

\section{Conclusions}

In conclusion, effects of meteorological conditions on milk yield in sheep cannot be understood without assessing production among milking periods in the same year and the phases of lactation, especially if milking periods are long.

\section{Acknowledgements}

We thank the farmer who participated in this study and Bruce MacWhirter for assisting with the English version of the manuscript.

\section{References}

Arrébola FA, Abecia JA, Forcada F, Garcia A, Martín RA, Mesa O (2009) Effects of annual rainfall and farm on lamb production after treatment with melatonin implants in Merino sheep a 4-year study. New Zealand Veterinary Journal 57:141-145.

Barash H, Silanikove N, Shamay A, Ezra E (2001) Interrelationships among ambient temperature, day length and milk yield in dairy cows under a Mediterranean climate. Journal of Dairy Science 84:2314-2320.

Blackshaw JK, Blackshaw AW (1994) Heat stress in cattle and the effect of shade on production and behaviour a review. Australian Journal of Experimental Agriculture 34:285-295.

Bohmanova J, Misztal I, Colet JB (2007) Temperature-humidity indices as indicators of milk production losses due to heat stress. Journal of Dairy Science 90:1947-1956.

Caroprese M, Albenzio M, Bruno A, Fedele V, Santillo A, Sevi A (2011) Effect of solar radiation and flaxseed supplementation on milk production and fatty acid profile of lactating ewes under high ambient temperature. Journal of Dairy Science 94:3856-3867.

Carta A, Sanna SR, Casu S (1995) Estimating lactation curves and seasonal effects for milk, fat and protein in Sarda dairy sheep with a test day model. Livestock Production Science 44:37-44.

Cincović MR, Belić BM, Toholj BD, Radović IV, Vidović BR (2010) The influence of THI values at different periods of lactation on milk quality and characteristics of lactation curve. Journal of Agricultural Science 55:235-241.

Echeverri-Zuluaga JJ, Restrepo LF (2009) Efecto meteorológico sobre la producción y calidad de la leche en dos Municipios de Antioquia - Colombia. [Meteorological effect on milk production and quality in two villages of Antioquia, Colombia] Revista del Centro de Investigación. Universidad La Salle 6:50-57.

Eyal E, Lawi A, Folman Y, Morag M (1978) Lamb and milk production of a flock of dairy ewes under an accelerated breeding regime. Journal of Agricultural Science 91:69-79.

Finch VF (1985) Comparison of Non-evaporative heat transfer in different cattle breeds. Australian Journal of Agriculture Research $36: 497-508$.

Finocchiaro R, van Kaam JBCHM, Portolano B, Misztal I (2005) Effect of heat stress on production of Mediterranean dairy sheep. Journal of Dairy Science 88:1855-1864.

Finocchiaro R, van Kaam JBCHM, Portolano B (2007) Effect of weather conditions on somatic cell score in Sicilian Valle del Belice ewes. Italian Journal of Animal Science 6:130-132.

Gomes Da Silva RG (2006) Weather and climate and animal production. In Guide to agricultural meteorological practices GAMP. http //www.agrometeorology.org/filesfolder/repository/gamp_chap_11.pdf. Accessed 20 Jan 2017.

Gootwine E, Pollott GE (2000) Factors affecting milk production in Improved Awassi dairy ewes. Animal Science 71:607-615.

IBM Corp (2013) IBM SPSS Statistics for Windows, Version 22.0. Armonk, NY IBM Corp.

Lewis RM, Notter DR, Hogue DE, Magee BH (1996) Ewe fertility in the STAR accelerated lambing system. Journal of Animal Science 74:1511-1522.

Lu CD (1989) Effects of heat stress on goat production. Small Ruminant Research 2: 151-162.

Marai IFM, El-Darawany AA, Fadiel A, Abdel-Hafez MAM (2007) Physiological traits as affected by heat stress in sheep-a review. Small Ruminant Research 71:1-12.

Menegatos J, Goulas C, Kalogiannis D (2006) The productivity, ovarian and thyroid activity of ewes in an accelerated lambing system in Greece. Small Ruminant Research 65:209-216.

Naskar S, Gowane GR, Chopra A, Paswan C, Prince LLL (2012) Genetic Adaptability of Livestock to Environmental Stresses. In: Sejian V, Naqvi SMK, Ezeji T, Lakritz J, Lal R (ed) Environmental Stress and Amelioration in Livestock Production. Springer Berlin Heidelberg, pp 317-378.

Novák P, Vokřálová J, Knížková I, Kunc P, Rožnovský J (2007) The influence of high ambient temperatures in particular stages of lactation on milk production of Holstein dairy cows. In: Střelcová $\mathrm{K}$, Škvarenina J, Blaženec M (ed) Bioclimatology and Natural Hazards. Pol'ana nad Detvou.

Novák P, Vokřálová J, Broucek J (2009) Effects of the stage and number of lactation on milk yield of dairy cows kept in open barn during high temperatures in summer months. Archiv fur Tierzucht 52:574-586.

Peana I, Fois G, Cannas A (2007) Effects of heat stress and diet on milk production and feed and energy intake of Sarda ewes. Italian Journal of Animal Science 6:577-579.

Phelan P, Morgan ER, Rose H, Grant J, O'kiely, P (2016) Predictions of future grazing season length for European dairy, beef and sheep farms based on regression with bioclimatic variables. Journal of Agricultural Science 154:765-781. 
Pluske JM, Slade AM, Vercoe PE (2010) A Weather and wether effects of wind, temperature and rain on sheep feedlot production. Australasian Agribusiness Review 18:11.

Ramón M, Díaz C, Pérez-Guzman MD, Carabaño MJ (2016) Effect of exposure to adverse climatic conditions on production in Manchega dairy sheep. Journal of Dairy Science 99:1-16.

Salama AAK, Caja G, Hamzaouia S, Badaoui B, Castro-Costa A, Facanha DAE, Guilhermino MM, Bozzi R (2014) Different levels of response to heat stress in dairy goats. Small Ruminant Research 121:73-79.

Scocco P, Piermarteri K, Malfatti A, Tardella FM, Catorci A (2016) Short communication Effects of summer rainfall variations on sheep body state and farming sustainability in sub-Mediterranean pastoral systems. Spanish Journal of Agricultural Research 14:e03SC02.

Sevi A, Annicchiarico G, Albenzio M, Taibi L, Muscio A, Dell'Aquila S (2001) Effects of solar radiation and feeding time on behavior, immune response and production of lactating ewes under high ambient temperature. Journal of Dairy Science 84:629-640.

Silanikove N (2000) Effects of heat stress on the welfare of extensively managed domestic ruminants. Livestock Production Science 67:1-18.

West JW, Mullinix BG, Bernard JK (2003) Effects of hot, humid weather on milk temperature, dry matter intake, and milk yield of lactating dairy cows. Journal of Dairy Science 86:232-242. 